\title{
Soil Microbial Community Based on PLFA Profiles in an Age Sequence of Pomegranate Plantation in the Middle Yellow River Floodplain
}

\author{
Shilin Wang ${ }^{1,2}$, Xinyu Yan ${ }^{1,2}$, Dong Wang ${ }^{1}{ }^{D}$, Imran Ahammad Siddique ${ }^{3,4}$, Ji Chen ${ }^{3,5,6}$, Qi Xu ${ }^{1}$, Cancan Zhao ${ }^{1}$, \\ Leyun Yang ${ }^{7}$, Yuan Miao ${ }^{1,2, *}$ and Shijie Han ${ }^{1,2, *}$ \\ 1 International Joint Research Laboratory of Global Change Ecology, School of Life Sciences, Henan University, \\ Kaifeng 475004, China; 104753190825@henu.edu.cn (S.W.); 104753201074@henu.edu.cn (X.Y.); \\ wangd@henu.edu.cn (D.W.); xqqq_x@163.com (Q.X.); czhao@henu.edu.cn (C.Z.) \\ 2 Yellow River Floodplain Ecosystems Research Station, Henan University, Xingyang 450100, China \\ 3 Department of Agroecology, Aarhus University, 8830 Tjele, Denmark; imran.siddique@agro.au.dk (I.A.S.); \\ ji.chen@agro.au.dk (J.C.) \\ 4 Department of Soil Science, Bangladesh Agricultural University, Mymensingh 2202, Bangladesh \\ 5 Aarhus University Centre for Circular Bioeconomy, Aarhus University, 8830 Tjele, Denmark \\ 6 iCLIMATE Interdisciplinary Centre for Climate Change, Aarhus University, 4000 Roskilde, Denmark \\ 7 College of Animal Science and Technology, Henan University of Science and Technology, \\ Luoyang 471023, China; 190319250874@stu.haust.edu.cn \\ * Correspondence: miaoyuan@vip.henu.edu.cn (Y.M.); hansj@iae.ac.cn (S.H.)
}

check for

updates

Citation: Wang, S.; Yan, X.; Wang, D.; Siddique, I.A.; Chen, J.; Xu, Q.; Zhao, C.; Yang, L.; Miao, Y.; Han, S. Soil Microbial Community Based on PLFA Profiles in an Age Sequence of Pomegranate Plantation in the Middle Yellow River Floodplain. Diversity 2021, 13, 408. https:/ / doi.org/10.3390/d13090408

Academic Editor: Tine Grebenc

Received: 11 July 2021

Accepted: 24 August 2021

Published: 27 August 2021

Publisher's Note: MDPI stays neutral with regard to jurisdictional claims in published maps and institutional affiliations.

Copyright: (c) 2021 by the authors Licensee MDPI, Basel, Switzerland. This article is an open access article distributed under the terms and conditions of the Creative Commons Attribution (CC BY) license (https:// creativecommons.org/licenses/by/ $4.0 /)$.

\begin{abstract}
Pomegranate (Punica granatum L.) is one of the most important fruit trees in semi-arid land Previous studies were primarily focused on soil microbial community composition under different pomegranate plantation managements. However, soil microbial community composition under longterm pomegranate plantation has rarely been studied. We investigated pomegranate plantation along with an age sequence (i.e., 1, 3, 5, and 10 years after pomegranate plantation; abbreviated by P1, P3, P5, P10, respectively) in the Middle Yellow River floodplain. Our objectives were to address (1) variations of soil physicochemical properties and (2) changes in soil microbial community composition and the influential factors. The results demonstrated that the soil water content of pomegranate plantation decreased with the increase of pomegranate plantation stand age. Specifically, dissolved organic carbon, ammonium, and available phosphorus increased significantly with stand age both at 0-10- and 10-20$\mathrm{cm}$ soil depths. The P10 had the highest microbial phospholipid fatty acid (PLFA) profiles, including fungi, bacteria, Gram-positive bacteria, Gram-negative bacteria, and arbuscular mycorrhizal fungi. The ratio of fungal PLFAs to bacterial PLFAs increased and the ratio of Gram-positive to Gram-negative bacterial PLFAs decreased along the pomegranate plantation stand age. Dissolved organic carbon was the most important influential factor among the studied variables, which explained $42.2 \%$ variation of soil microbial community. In summary, the long-term plantation of pomegranate elevated soil microbial biomass and altered microbial community composition.
\end{abstract}

Keywords: available phosphorus; bacteria; dissolved organic carbon; fungi; pomegranate plantation; plant stand age; Yellow River

\section{Introduction}

As an important edible fruit species, pomegranate (Punica granatum L.) has been emerged as an important cash crop in the arid and semi-arid regions in recent years [1,2]. For example, Chinese pomegranate industry production reached 1.70 million tons in 2017. The pomegranate tree, a cultural crop, is considered tolerant to soil water deficits [3]. It has been widely planted in the semi-arid regions of China, more broadly in the Middle Yellow River floodplain during recent years. Pomegranate plantation has profound impacts 
on soil physicochemical properties, especially soil microorganisms that are sensitive to pomegranate plantation $[4,5]$.

Soil microorganisms are integral parts of ecosystems, which play vital roles in nutrient availability in plant production systems. Availability of limiting nutrients such as nitrogen $(\mathrm{N})$ and phosphorus $(\mathrm{P})$ are attributed to symbiotic relationships between plants and microbes [6]. Numerous microbes present in rhizosphere interact either positively or negatively with plants. These interactions influence the nutrient dynamics on plant growth and development $[7,8]$. Besides, specific plant-microbe interactions including recruitment into rhizosphere, persistence, function, and turnover could enhance agricultural crop productivity [9]. Microbial diversity can support ecosystem functions such as plant productivity $[10,11]$. Soil microbial communities have key roles in supporting services like organic matter transformation [11], aggregate stability [12], and enzyme activity [13,14] to support and sustain the plant growth. For instance, symbiotic relationships between arbuscular mycorrhizal fungi (AMF) and plant roots enable phosphate accessibility away from the root surface to overcome the phosphorus deficiency problems. Introduction of pomegranate plantation can alter the soil microbial community [15], whereas the effects of pomegranate plantation stand age on the soil microbial community need to be more explored.

Many factors, including soil type [9], ecosystem type [16], land-use type [17], and human activity [18] can influence microbial community composition and activity. For instance, soil temperature and moisture influence the soil microbial community composition by altering substrate availability [11]. Similarly, soil organic carbon (SOC), available N, and soil $\mathrm{pH}$ have substantial influence on microbial structure [19,20]. Long-term plantation may influence soil physicochemical properties, directly leading to changes in soil microbial community composition. For example, long-term crop mulching in persimmon orchards changes both soil properties and bacterial relative abundance and composition [21]. Although the initial soil conditions are similar, the microbial community may shift over time under long-term plantation. A 35-year long-term restoration study showed that afforestation significantly increased SOC and total $\mathrm{N}$, while bacterial species richness and phylogenetic diversity declined [22]. The changes of soil physicochemical properties under long-term plantation resulted in the shifts of microbial community composition. For example, long-term hybrid poplar plantation resulted in lower SOC mineralization that favored fungal community growth rather than bacterial community growth [23]. Therefore, long-term plantation has the potential to shift the abundance of the soil microbial community.

The analysis of phospholipid fatty acid profiles can depict the actual microbial community status, and it is a rapid and inexpensive technique to determine biomass and community structure [24]. Lipids in microbe can be extracted from the soils by homogenization and centrifugation. Samples were then redissolved in hexane solvent containing nonadecanoic acid methyl ester as an internal standard and analyzed with a gas chromatograph [25]. In recent years, methods based on nucleic acid extraction and analyses have often been preferred to PLFA analysis for studying microbial communities in environmental samples. However, the PLFA method still holds several advantages above other methods and may be even more sensitive in detecting shifts in the microbial community structure when compared to nucleic acid base methods [26]. Based on these reasons, we analyzed soil microbial communities using the PLFA method.

Stand age affects the cycling and supply of soil nutrients, directly leading to changes in soil physicochemical properties and soil microbial communities. Significant research has primarily focused on the soil properties under different managements in the plantation [27-29], but the dynamics of microbial community under the same management along plantation stand age is still not clear, especially in pomegranate plantation. To close these knowledge gaps, we investigated the effects of pomegranate plantation of different stand ages on soil physicochemical properties and soil microbial community composition in the Middle Yellow River floodplain. We tried to address two specific questions: (1) Did microbial community composition respond to the stand age of pomegranate plantation? (2) What 
were the underlying mechanisms influencing the responses of microbial community to the stand age of pomegranate plantation in the Middle Yellow River floodplain?

\section{Materials and Methods}

\subsection{Research Site}

This study was conducted in the Yellow River Floodplain Ecosystems Research Station $\left(34^{\circ} 59^{\prime} 65^{\prime \prime} \mathrm{N}, 113^{\circ} 25^{\prime} 05^{\prime \prime} \mathrm{E}, 100 \mathrm{~m}\right.$ a.s.l), Henan Province, China. It is located on the point of demarcation of the middle and lower reaches of the Yellow River (Figure 1a). The climate is the monsoon dry climate of medium latitudes. According to data recorded for the years from 2010 to 2020 from the National Meteorological Information Center of China, the mean annual average air temperate was $14.3^{\circ} \mathrm{C}$, ranging from $-9.6^{\circ} \mathrm{C}$ in January to $42.5^{\circ} \mathrm{C}$ in July. The mean annual precipitation was $631.4 \mathrm{~mm}$, with $65 \%$ occurring from July to September. The average annual frost-free period was 222 days, and the average annual sunshine was $2322 \mathrm{~h}$. The main soil type was classified as sandy soil. Mean soil bulk density was $1.18 \mathrm{~g} / \mathrm{cm}^{3}$, and the soil $\mathrm{pH}$ was around 8.0.

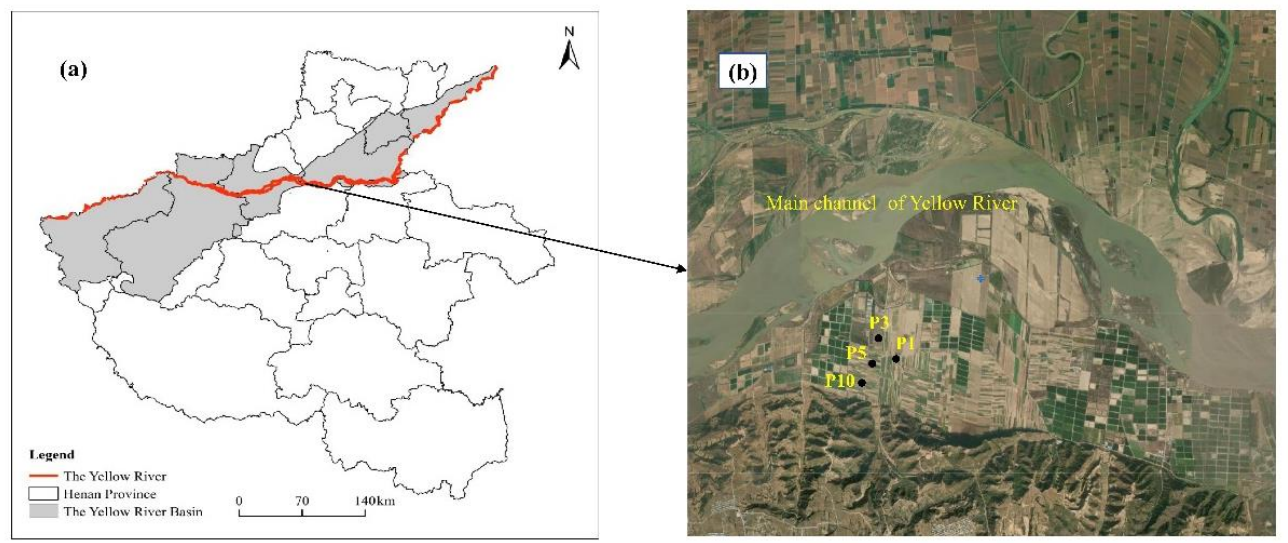

Figure 1. The experimental sitemap illustrating the location of Henan Province, China. (a) Gray area is the Yellow River basin and red line is the main channel of Yellow River. (b) The map demonstrates the sample sites in the floodplain of the Middle Yellow River; yellow points represent sample sites; pomegranate plantation for one year (P1), other names (P3; P5; P10) are in the same manner.

The experimental site for sampling had not been flooded by the Yellow River from the completion of Xiaolangdi Project in 1997. Pomegranates were the staple economy plantation in the floodplain. In the present study, four sites were selected, including P1 (pomegranates stand age of 1 year), P3 (pomegranates stand age of 3 years), P5 (pomegranates stand age of 5 years), and P10 (pomegranates stand age of 10 years). As the entire studied site belonged to one farmer, they received the same management including irrigation frequency and irrigation rate, $1.5 \mathrm{tha}^{-1}$ inorganic fertilizer, and $3.0 \mathrm{tha}^{-1}$ organic fertilizer inputs every year, and no-tillage and weed control. Pomegranate tree growth conditions and particle size distribution of soil is shown in Table 1.

Table 1. Tree growth condition and particle size analysis in pomegranate plantations with an age sequence of pomegranate plantation.

\begin{tabular}{cccccccc}
\hline \multirow{2}{*}{$\begin{array}{c}\text { Stand } \\
\text { Age }\end{array}$} & \multicolumn{3}{c}{ Tree Growth Condition $(\mathbf{c m})$} & \multicolumn{3}{c}{ Particle Size Analysis (\%) } \\
\cline { 2 - 8 } & $\begin{array}{c}\text { Basal } \\
\text { Diameter }\end{array}$ & Height & $\begin{array}{c}\text { Crown } \\
\text { Height }\end{array}$ & $\begin{array}{c}\text { Crown } \\
\text { Width }\end{array}$ & Clay & Silt & Sand \\
\hline P1 & 1.43 & 128.90 & 93.62 & 33.02 & 0.44 & 70.10 & 29.46 \\
P3 & 2.74 & 234.85 & 175.84 & 76.04 & 0.02 & 67.39 & 32.58 \\
P5 & 7.57 & 215.87 & 154.04 & 101.01 & 0.05 & 71.91 & 28.04 \\
P10 & 10.13 & 303.89 & 243.52 & 186.87 & 0.12 & 63.34 & 36.54 \\
\hline
\end{tabular}




\subsection{Sample Collection and Processing}

Different pomegranate plantations of 1,3,5, and 10 years were chosen for sampling in September 2020 (Figure 1b). For each plant stand age, we evenly divided each selected site into five blocks. Three soil samples were taken and mixed in each block by a $4-\mathrm{cm}$ diameter soil drilling sampler at depths of $0-10,10-20$, and $20-30 \mathrm{~cm}$. There were in total 60 mixed soil samples. Visible roots and other debris were firstly removed from the soil samples. Then the soil samples were passed through a 2-mm sieve. Each sample was divided into two subsamples. One subsample was transported to the laboratory and stored at $-20{ }^{\circ} \mathrm{C}$ in a refrigerator for microbial analysis. Another subsample was used to measure soil physical and chemical properties. Additionally, undisturbed soil samples were collected using a soil corer (stainless steel cylinder of $100 \mathrm{~cm}^{3}$ in volume) to determine soil bulk density (BD).

Subsamples for soil BD analyses were oven-dried at $105^{\circ} \mathrm{C}$ to a constant weight and weighed. Soil particle size was measured by a particle size analyzer (Mastersizer 3000, Malvern, UK). Soil water content (SWC, g of water per $100 \mathrm{~g}$ dry soil) was determined by oven-drying (ZXRD_A7230, Zhicheng, Shanghai, China) at $105^{\circ} \mathrm{C}$ to a constant weight, and weighed. Soil $\mathrm{pH}$ was determined on two subsamples from each depth, using a 2.5:1 ratio of deionized water/air-dried soil and measured by a $\mathrm{pH}$ meter (PB-10, Sartorius, Germany). Dissolved organic carbon that extracted with $0.5 \mathrm{M} \mathrm{K}_{2} \mathrm{SO}_{4}$ of fresh soil sample was measured with a TOC analyzer (vario TOC cube, Elementar, Germany). Ammonium $\left(\mathrm{NH}_{4}-\mathrm{N}\right)$ and nitrate $\left(\mathrm{NO}_{3}-\mathrm{N}\right)(2 \mathrm{M}$ of $\mathrm{KCl}$ as an extractant) of fresh soil sample were measured with a flow injection autoanalyzer (Westco Model 200, Smart Chem, France). The available phosphorus (AP) of dry soil sample was extracted with $0.5 \mathrm{M}$ of $\mathrm{NaHCO}_{3}$ following the measurement by Bell and Doisy method [30] with a UV Spectrophotometer (UV-1900, Daojin, Japan).

\subsection{Phospholipid Fatty Acid Analysis}

The soil microbial community was characterized using phospholipid fatty acids (PLFAs) analysis. The separation and purification of PLFAs were performed as described by Bossio and Scow [31]. The fatty acid fractions of PLFAs were analyzed separately on a gas chromatograph with a flame ionization detector (FID) (GC6890, Agilent Technologies, Bracknell, UK) by automatic injection of aliquots. For each sample, different PLFAs were considered be the representative of different groups of soil microorganisms [32]. The fatty acid concentration was taken as an indicative of total biomass and calculated based on Abaye's research [33]. The abundance of individual fatty acids was determined as relative nmol per $g$ of dry soil and standard nomenclature was used [34].

Characteristic fatty acids were grouped into biomarkers for the following microbial groups: Gram-positive bacteria (GP) (15:0, i15:0, a15:0, i16:0, a16:0, a17:0, i17:0, a18:0) [35,36]; Gram-negative bacteria (GN):(16:1 $\omega 7 \mathrm{c}$, cy17:0, cy19:0, 18:1 $\omega 6 \mathrm{c}, 18: 1 \omega 7 \mathrm{c}, 17: 1 \omega 8 \mathrm{c})$; bacteria (B) (i15:0, a15:0, 15:0, i16:0, 16:1 $\omega 7 \mathrm{c}$, i17:0, a17:0, cy17:0, cy19:0, 17:1 $\omega 8 \mathrm{c}, 18: 1 \omega 7 \mathrm{c}$ ); and fungi (F) (16:1 $\omega 5 c, 18: 1 \omega 9 c, 18: 2 \omega 6,9 c)$ [25,35,37]; AMF (6:1 $\omega 5 c, 18: 1 \omega 9 c, 18: 2$ $\omega 6,9 c)[24,36]$.

\subsection{Statistical Analysis}

The data were examined for normality and log- or cubed- or root-converted to satisfy the assumptions for statistical analysis. We used one-way analysis of variance (ANOVA) with an LSD test to analyze the differences of soil physical (BD, SWC) and chemical characteristics $\left(\mathrm{pH}, \mathrm{DOC}, \mathrm{NH}_{4}-\mathrm{N}, \mathrm{NO}_{3}-\mathrm{N}, \mathrm{AP}\right)$ in pomegranate plantation with different standing ages and soil depths. Two-way ANOVA was used to test the statistical significance of plantation standing age, soil depths, and their interactions on soil microbial community changes (total PLFAs, bacterial PLFAs, fungal PLFAs, F/B ratios, GP bacterial PLFAs, GN bacterial PLFAs, GP/GN ratios, and AMF PLFAs). Pearson correlations analysis was performed among microbial communities and soil physicochemical properties. Difference was significant at the 0.05 level. These statistical analyses were carried out with SPSS 20 (SPSS, Inc., Chicago, IL, USA). Redundancy analysis (RDA) was performed to quantify the 
correlations between soil microbial community and soil property variables using Canoco 5.0 (Microcomputer Power, American, www.microcomputerpower.com).

\section{Results}

\subsection{PLFAs for Microbial Community}

There were significant effects of pomegranate plantation stand age on total microbial PLFAs $\left(16.82,24.22,30.78,39.51 \mathrm{nmol} \mathrm{g}^{-1}\right.$ for P1, P3, P5, and P10 at $0-10 \mathrm{~cm}, 10.02,13.61,16.32$, $18.70 \mathrm{nmol} \mathrm{g}^{-1}$ at $10-20 \mathrm{~cm}$, respectively; $p<0.05$; Figure 2a; Table S1). Total PLFAs, bacterial PLFAs (GP bacterial PLFAs and GN bacterial PLFAs), fungal PLFAs, and AMF PLFAs were significantly higher in $\mathrm{P} 10$ than either $\mathrm{P} 1$ or $\mathrm{P} 3$ at $0-10 \mathrm{~cm}$ soil depth $(p<0.05)$, with increases of $134.89 \%, 128.87 \%$ (115.10\% and $131.62 \%), 177.13 \%$, and $166.61 \%$, respectively in P10 compared to P1. No significant difference was found between P3 and P5 for total PLFAs, bacterial PLFAs (GP bacterial PLFAs and GN bacterial PLFAs), fungal PLFAs, and AMF PLFAs. Total PLFAs, bacterial PLFAs, fungal PLFAs, GP bacterial PLFAs, GN bacterial PLFAs, and AMF PLFAs at $0-10 \mathrm{~cm}$ were significantly greater than at $10-20-$ or $20-30-\mathrm{cm}$ soil depths, but no significant difference was found between 10-20- and 20-30-cm soil depths $(p<0.05)$ (Figures 2a-c and 3a,b,d; Table S1).

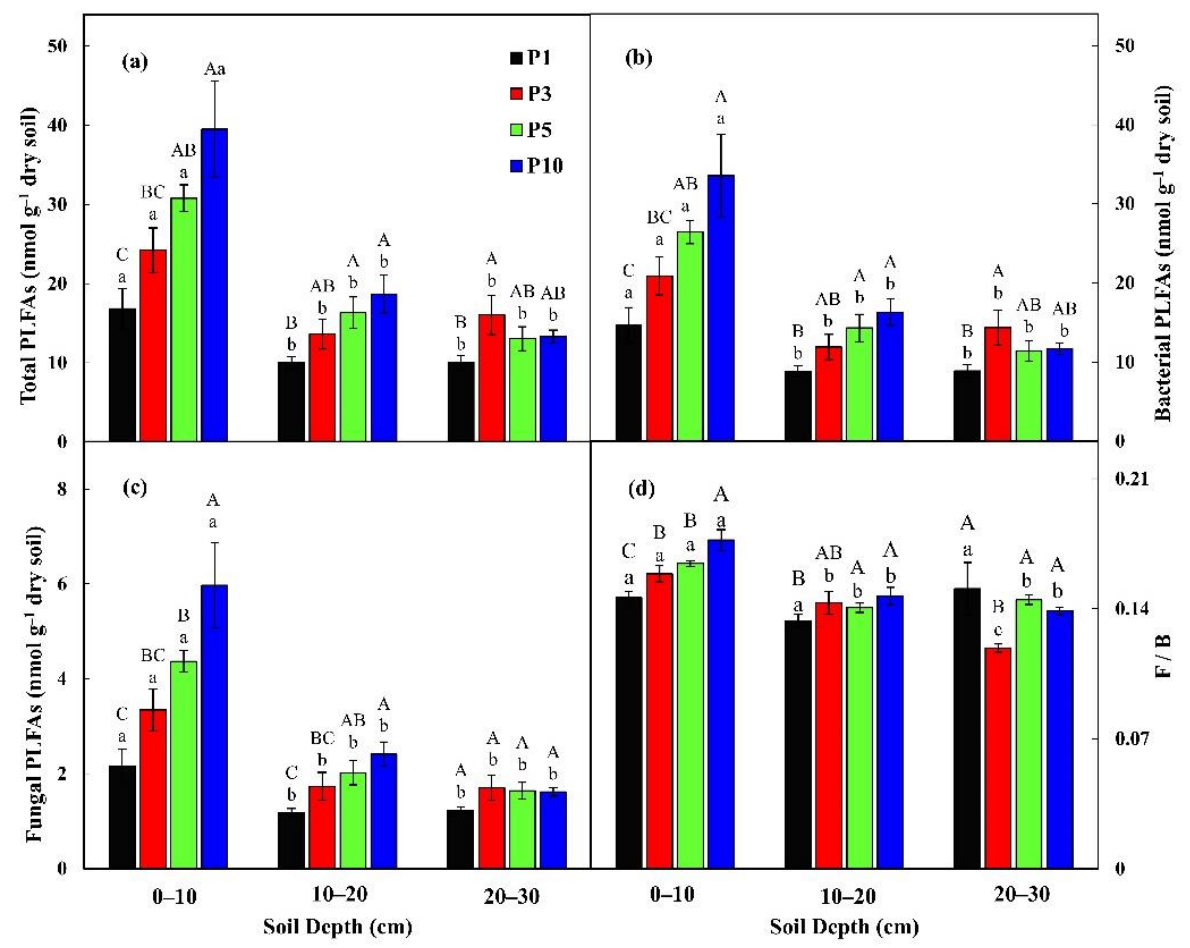

Figure 2. Soil total PLFAs (a), bacterial PLFAs (b), fungal PLFAs (c), and F/B ratios (d) in different soil depths $(0-10,10-20$, and 20-30 cm) under pomegranate plantation of different years. Values followed by a different uppercase letter are significant difference $(p<0.05)$ between different years in the same soil depth; values followed by a different lowercase letter are significant difference between three soil depths in the same year. (P1, pomegranate plantation for 1 year; other names (P3; P5; P10) are in the same manner; error values are mean \pm standard error; $n=5$ ). 


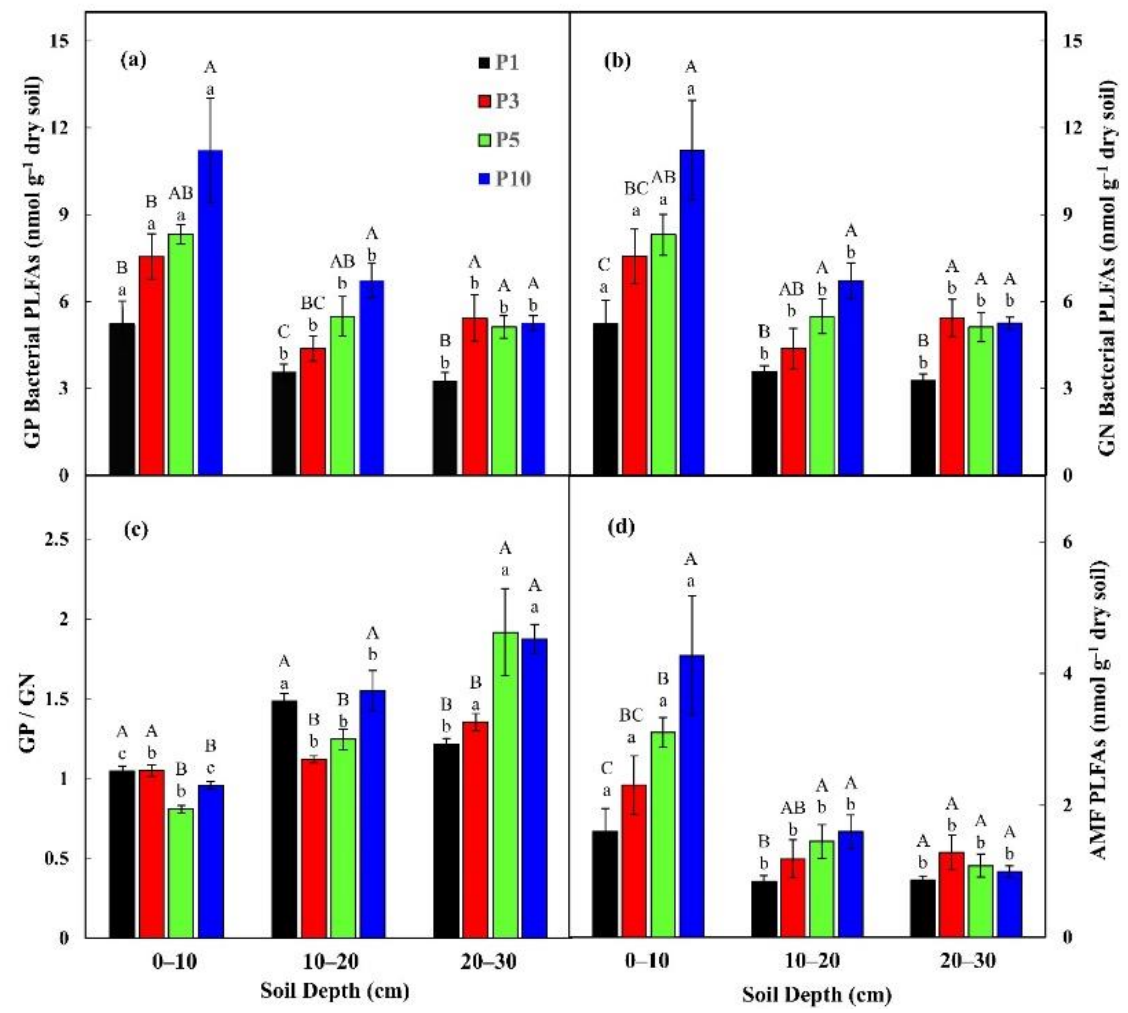

Figure 3. GP bacterial PLFAs (a), GN bacterial PLFAs (b), GP/GN: the ratio of GP bacterial PLFAs to GN bacterial PLFAs (c), AMF PLFAs: arbuscular mycorrhizal fungal PLFAs (d) in pomegranate plantation of different years at different soil depths $(0-10,10-20$, and $20-30 \mathrm{~cm})$. (Values followed by a different uppercase letter are significant difference $(p<0.05)$ of different years in same soil depth; values followed by a different lowercase letter are significant difference of three soil depths in same year. P1, pomegranate plantation for 1 year; other names (P3; P5; P10) are in the same manner; error values are mean \pm standard error; $n=5$ ).

The ratio of fungal PLFAs to bacterial PLFAs increased significantly along plantation stand age both at $0-10$ and $10-20 \mathrm{~cm}$, but not at $20-30 \mathrm{~cm}$ (Figure 2d; Table S1). GP/GN ratios (the ratio of GP bacterial PLFAs to GN bacterial PLFAs) at $0-10 \mathrm{~cm}$ in P1 and P3 were higher than P5 and P10 $(p<0.05)$, but P5 and P10 were significantly higher than P1 and P3 at 20-30 cm (Figure 3c). Two-way ANOVA showed that total PLFAs, fungal PLFAs, bacterial PLFAs, GP bacterial PLFAs, GN bacterial PLFAs, AMF PLFAs, and the F/B ratio (the ratio of fungal PLFAs to bacterial PLFAs) increased significantly along plantation stand age $(p<0.01)$, and GP/ GN ratio increased at $0-10$-cm soil depth $(p<0.05$, Table 2; Figure 4).

All PLFAs and the F/B ratio increased significantly along the stand age of pomegranate plantations and had a significant difference at $0-10-\mathrm{cm}$ soil depth (Table S1). Besides, the GP/GN ratio decreased at $0-10 \mathrm{~cm}(p<0.05)$, but increased at 20-30-cm soil depth $(p<0.05)$ (Figures 2 and 3; Table 2). The interaction between pomegranate plant ages and soil depths was significant $(p<0.01)$ except GP bacterial PLFAs (Table 2). 
Table 2. Statistical significance of the effects of stand ages, soil depths and their interactions on soil properties and soil microbial communities (two-way ANOVA).

\begin{tabular}{|c|c|c|c|}
\hline & Stand Age (S) & Depth (D) & $\mathbf{S} \times \mathbf{D}$ \\
\hline $\mathrm{BD}$ & NS & - & - \\
\hline SWC & $10.179 * * *$ & NS & NS \\
\hline $\mathrm{pH}$ & $17.218^{* * *}$ & $10.360 * * *$ & $8.956^{* * *}$ \\
\hline DOC & $7.835^{* * *}$ & $15.172 * * *$ & $3.872 * *$ \\
\hline $\mathrm{NH}_{4}-\mathrm{N}$ & $62.039 * * *$ & NS & NS \\
\hline $\mathrm{NO}_{3}-\mathrm{N}$ & $8.572 * * *$ & NS & NS \\
\hline $\mathrm{AP}$ & $124.783^{* * *}$ & $101.777^{* * *}$ & $41.197^{* * *}$ \\
\hline Total PLFAs & $10.008^{* * *}$ & $38.887 * * *$ & $3.214^{* *}$ \\
\hline Bacterial PLFAs & $9.579 * * *$ & $36.743 * * *$ & $3.045 *$ \\
\hline Fungal PLFAs & $12.489 * * *$ & $34.215^{* * *}$ & $4.403 * *$ \\
\hline $\mathrm{F} / \mathrm{B}$ ratio & $5.199 * *$ & $28.114^{* * *}$ & $5.532 * * *$ \\
\hline GP bacterial PLFAs & $12.073 * * *$ & $23.820 * * *$ & NS \\
\hline GN bacterial PLFAs & $7.952 * * *$ & $56.704^{* * *}$ & $4.403 * *$ \\
\hline GP/GN ratio & $4.701 * *$ & $40.835^{* * *}$ & $6.798^{* * *}$ \\
\hline AMF PLFAs & $10.029 * * *$ & $51.315^{* * *}$ & $4.875^{* *}$ \\
\hline
\end{tabular}

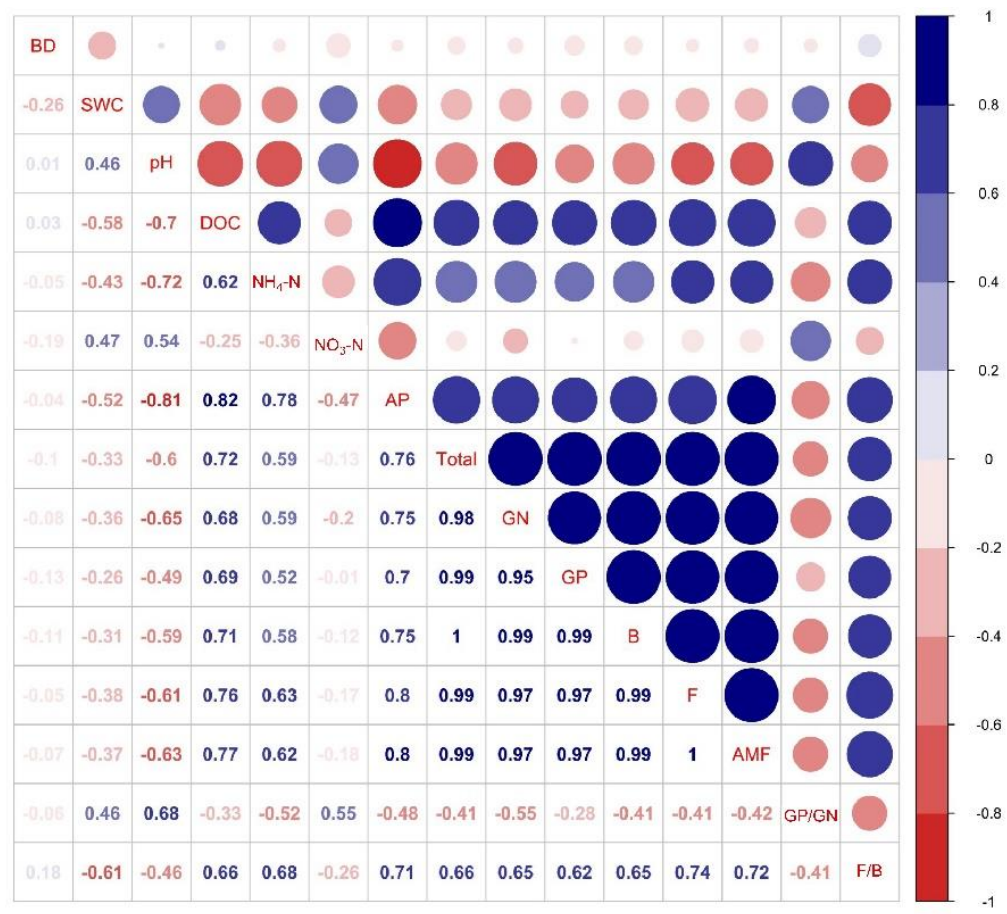

Figure 4. Pearson correlation coefficients $(r)$ between soil microbial PLFAs and soil physicochemical properties at $0-10 \mathrm{~cm}$ soil in pomegranate plantation of different years. (Total: total PLFAs; GN: Gram-negative bacterial PLFAs; GP: Gram-positive bacterial PLFAs; B: bacterial PLFAs; F: fungal PLFAs; AMF: arbuscular mycorrhizal fungal PLFAs; GP/GN: the ratio of Gram-positive bacterial PLFAs to Gram-negative bacterial PLFAs; F/B: the ratio of fungal PLFAs to bacterial PLFAs; BD: bulk density; SWC: soil water content; DOC: dissolved organic carbon; AP: available phosphorus; Blue color represents positive correlation; red color represents negative correlation; bubble sizes represent the values of $\mathrm{r}$ ).

\subsection{Soil Physicochemical Properties and Relationships with Soil Microbial PLFAs}

Plant stand age did not affect BD at $0-10-\mathrm{cm}$ soil depth (Table 3). SWC, soil pH, DOC, $\mathrm{NH}_{4}-\mathrm{N}, \mathrm{NO}_{3}-\mathrm{N}$, and AP differed significantly with different pomegranate plantation stand ages. Soil pH, DOC, and AP differed significantly between different soil depths (Table 3). Soil $\mathrm{pH}$ and DOC in P5 and P10 were significantly lower than P1 and P3 at the same soil depth $(p<0.05)$. Soil $\mathrm{pH}$ was the highest at $20-30 \mathrm{~cm}$ and the lowest at $0-10 \mathrm{~cm}$ across the various 
plant ages. The $\mathrm{P} 1$ had the highest $\mathrm{pH}$ in all pomegranate plantations, with a downward trend on soil $\mathrm{pH}$ along the increasing of pomegranate plantation stand age at $0-10 \mathrm{~cm}(p<0.001)$. DOC content at $0-10 \mathrm{~cm}$ in P10 significantly increased to $100.40 \pm 6.65 \mathrm{mg} \mathrm{kg}^{-1}(p<0.05)$ compared to P1 (62.09 $\left.\pm 6.64 \mathrm{mg} \mathrm{kg}^{-1}\right), \mathrm{P} 3\left(54.78 \pm 4.27 \mathrm{mg} \mathrm{kg}^{-1}\right)$ and P5 (72.69 $\pm 4.69 \mathrm{mg} \mathrm{k}^{-1}$, Table 3). $\mathrm{NH}_{4}-\mathrm{N}$ in P5 and P10 were significantly higher than either P1 or P3 in all soil depths $(p<0.05)$. Remarkably, $\mathrm{P} 5$ had the lowest $\mathrm{NO}_{3}-\mathrm{N}$ content compared to other treatments in all soil depths. Mean AP increased along the plantation stand age from 7.25 to $123.53,5.55$ to $46.46,4.74$, to $12.21 \mathrm{mg} \mathrm{kg}^{-1}$ at $0-10,10-20$, and 20-30-cm soil, respectively.

The Pearson correlation analysis showed that total PLFAs, bacterial PLFAs, fungal PLFAs, GP bacterial PLFAs, GN bacterial PLFAs, and AMF PLFAs were positively correlated to DOC, $\mathrm{NH}_{4}-\mathrm{N}, \mathrm{AP}$, and negatively correlated to soil $\mathrm{pH}(p<0.05)$. The ratio of GP bacterial PLFAs to GN bacterial PLFAs was positively related to SWC $(p<0.05)$, soil $\mathrm{pH}(p<0.01), \mathrm{NO}_{3}-\mathrm{N}(p<0.05)$, and negatively related to $\mathrm{NH}_{4}-\mathrm{N}$ and $\mathrm{AP}(p<0.05)$. The ratio of fungal PLFAs to bacterial PLFAs was positively related to DOC, $\mathrm{NH}_{4}-\mathrm{N}$, and AP $(p<0.01)$, negatively related to SWC, $\mathrm{pH}(p<0.01, p<0.05$, Figure 4$)$.

There were significant relationships between soil microbial PLFAs and environment variables (BD, SWC, $\mathrm{pH}, \mathrm{DOC}, \mathrm{NH}_{4}-\mathrm{N}, \mathrm{NH}_{3}-\mathrm{N}$, and $\mathrm{AP}$ ) at $0-10-\mathrm{cm}$ soil depth (Figure 5). All seven environmental variables explained $56.6 \%$ of the total variability in the microbial PLFAs. The RDA analysis showed that axis 1 was mainly related to DOC which explained $55.86 \%$ of the variance, and the RDA axis 2 was mainly related to $\mathrm{NO}_{3}-\mathrm{N}$ which explained $0.58 \%$. The composition of soil microbial community at $0-10$-cm soil depth was significantly related to DOC, which explained $42.20 \%$ variations of soil microbial community. DOC contributed $74.60 \%$ in all environmental variables $(F=10.09, p=0.004$; Figure 5).

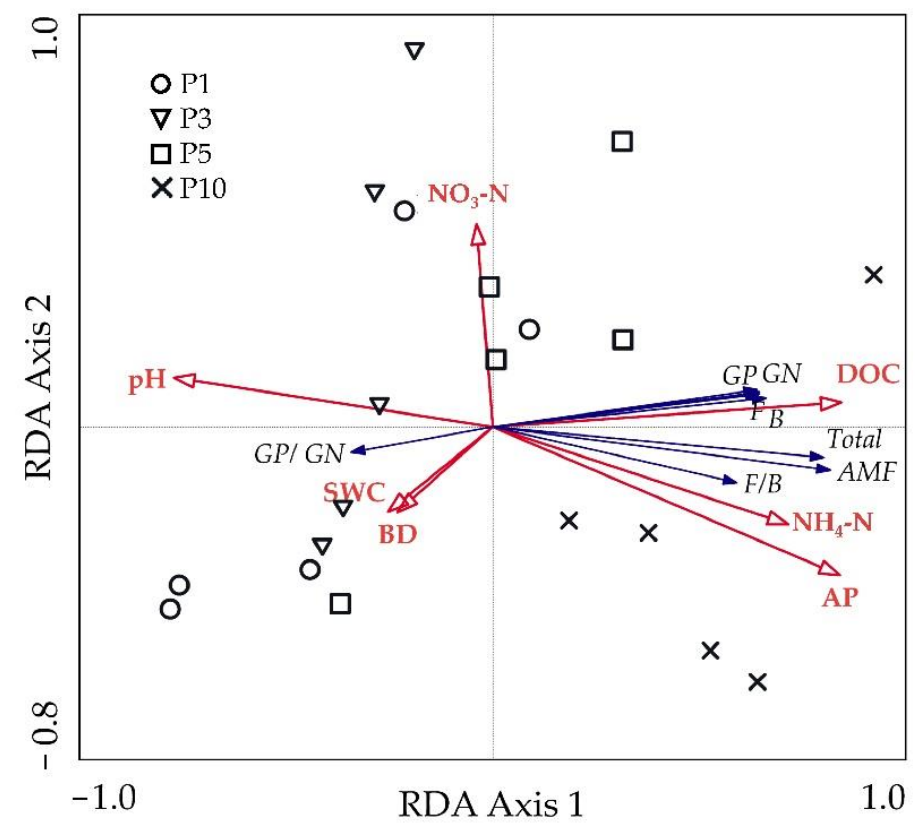

Figure 5. Redundancy analysis (RDA) results of PLFA profiles for the soil samples used seven microbial PLFAs and seven environmental variables in 0-10-cm soil. (P1, P3, P5, P10 represent soil microbial PLFAs in pomegranate plantation of 1, 3, 5, 10 years, respectively; DOC: dissolved organic carbon; AP: available phosphorus; BD: bulk density; SWC: soil water content; Total: total PLFAs; B: bacterial PLFAs; F: fungal PLFAs; F/B: the ratio of fungal PLFAs to bacterial PLFAs; GP: Grampositive bacterial PLFAs; GN: Gram-negative bacterial PLFAs; GP/GN: the ratio of Gram-positive bacterial PLFAs to Gram-negative bacterial PLFAs; AMF: arbuscular mycorrhizal fungal PLFAs). 
Table 3. Changes of soil BD, SWC, $\mathrm{pH}, \mathrm{DOC}, \mathrm{NH}_{4}-\mathrm{N}, \mathrm{NO}_{3}-\mathrm{N}$, and $\mathrm{AP}$ in different soil depths along an age sequence of pomegranate plantation (ANOVA).

\begin{tabular}{|c|c|c|c|c|c|c|c|c|}
\hline Depth (cm) & Stand Age & BD $\left(\mathrm{kg} / \mathrm{m}^{3}\right)$ & SWC (\%) & $\mathrm{pH}$ & DOC (mg kg $\left.{ }^{-1}\right)$ & $\mathrm{NH}_{4}-\mathrm{N}\left(\mathrm{mg} \mathrm{kg}^{-1}\right)$ & $\mathrm{NO}_{3}-\mathrm{N}\left(\mathrm{mg} \mathrm{kg}^{-1}\right)$ & $\mathrm{AP}\left(\mathrm{mg} \mathrm{kg}^{-1}\right)$ \\
\hline \multirow{3}{*}{$0-10$} & P1 & $1.21 \pm 0.04 \mathrm{~A}$ & $14.73 \pm 2.06 \mathrm{Aa}$ & $8.10 \pm 0.05 \mathrm{Aa}$ & $62.09 \pm 6.64 \mathrm{BCa}$ & $3.76 \pm 0.03 \mathrm{Ba}$ & $19.16 \pm 4.62 \mathrm{ABa}$ & $7.25 \pm 0.92 \mathrm{Ca}$ \\
\hline & P3 & $1.15 \pm 0.03 \mathrm{~A}$ & $13.31 \pm 2.14 \mathrm{Aa}$ & $7.97 \pm 0.03 \mathrm{Bb}$ & $54.78 \pm 4.27 \mathrm{Ca}$ & $3.76 \pm 0.03 \mathrm{Ba}$ & $22.23 \pm 1.94 \mathrm{Aa}$ & $5.77 \pm 0.65 \mathrm{Ca}$ \\
\hline & P5 & $1.21 \pm 0.03 \mathrm{~A}$ & $8.97 \pm 0.72 \mathrm{Ba}$ & $7.88 \pm 0.04 \mathrm{Bc}$ & $72.69 \pm 4.69 \mathrm{Ba}$ & $3.91 \pm 0.05 \mathrm{Aa}$ & $8.85 \pm 2.18 \mathrm{Ba}$ & $64.85 \pm 5.37 \mathrm{Ba}$ \\
\hline \multirow{4}{*}{$10-20$} & $\mathrm{P} 1$ & - & $15.11 \pm 2.01 \mathrm{Aa}$ & $8.20 \pm 0.05 \mathrm{Aa}$ & $56.05 \pm 3.38 \mathrm{ABa}$ & $3.72 \pm 0.02 \mathrm{Ba}$ & $17.40 \pm 2.31 \mathrm{Aa}$ & $5.55 \pm 1.02 \mathrm{Ca}$ \\
\hline & P3 & - & $14.21 \pm 1.35 \mathrm{ABa}$ & $8.11 \pm 0.04 \mathrm{ABab}$ & $49.90 \pm 2.50 \mathrm{Ba}$ & $3.67 \pm 0.01 \mathrm{Bb}$ & $20.73 \pm 1.60 \mathrm{Aab}$ & $6.16 \pm 1.02 \mathrm{Ca}$ \\
\hline & P5 & - & $10.96 \pm 0.74 \mathrm{BCa}$ & $8.03 \pm 0.03 \mathrm{Bb}$ & $67.59 \pm 2.81 \mathrm{Aa}$ & $3.91 \pm 0.03 \mathrm{Aa}$ & $9.19 \pm 1.64 \mathrm{Bab}$ & $31.59 \pm 5.66 \mathrm{Bb}$ \\
\hline & P10 & - & $9.43 \pm 0.73 \mathrm{Ca}$ & $8.04 \pm 0.04 \mathrm{Bab}$ & $66.43 \pm 4.92 \mathrm{Ab}$ & $3.88 \pm 0.06 \mathrm{Aa}$ & $13.87 \pm 0.48 \mathrm{ABa}$ & $46.46 \pm 5.35 \mathrm{Ab}$ \\
\hline \multirow{3}{*}{$20-30$} & P3 & - & $16.04 \pm 0.88 \mathrm{Aa}$ & $8.16 \pm 0.03 \mathrm{Aa}$ & $54.52 \pm 1.29 \mathrm{Aa}$ & $3.68 \pm 0.02 \mathrm{Bb}$ & $13.02 \pm 2.74 \mathrm{ABb}$ & $5.82 \pm 0.55 \mathrm{Ba}$ \\
\hline & P5 & - & $10.70 \pm 1.11 \mathrm{Ba}$ & $8.21 \pm 0.01 \mathrm{Aa}$ & $54.21 \pm 1.82 \mathrm{Ab}$ & $3.89 \pm 0.02 \mathrm{Aa}$ & $7.90 \pm 1.44 \mathrm{Bb}$ & $15.15 \pm 1.57 \mathrm{Ab}$ \\
\hline & P10 & - & $8.47 \pm 0.83 \mathrm{Ba}$ & $8.09 \pm 0.08 \mathrm{Ba}$ & $51.84 \pm 2.76 \mathrm{Ac}$ & $3.97 \pm 0.06 \mathrm{Aa}$ & $11.30 \pm 0.83 \mathrm{ABa}$ & $12.21 \pm 1.83 \mathrm{Ac}$ \\
\hline
\end{tabular}

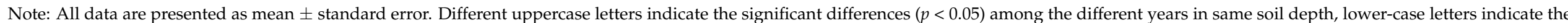

significant differences $(p<0.05)$ among the different soil depths in same year. (P1: pomegranate plantation of one year, other names (P3; P5; P10) are in the same manner; $n=5)$. 


\section{Discussion}

\subsection{Soil Properties in Pomegranate Plantation}

Our study revealed that DOC, $\mathrm{NH}_{4}-\mathrm{N}$, and AP enhanced significantly $(p<0.05)$ at $0-10-$ and $10-20-\mathrm{cm}$ soil depths along the pomegranate plantation stand age $(p<0.05)$. At $20-30-\mathrm{cm}$ soil depth, $\mathrm{NH}_{4}-\mathrm{N}$ and AP were significantly larger in P5 and P10 compared to P1 or P3 $(p<0.001 ;$ Table 3). Pomegranate plantation stand age had positive effects on soil nutrient availability in the Yellow River floodplain. Long-term plantation influenced soil properties by litter decomposition, rhizosphere secretions, and accumulation of fertilization [23]. For example, a study from a long-term apple orchard showed that organic carbon and available $\mathrm{N}$ and $\mathrm{P}$ content increased along the plant stand age [38]. The increase of soil organic carbon also was found in a long-term tea plantation [39]. Fertilization inputs can also improve soil nutrient availabilities [40]. Moreover, the long-term (21 years) experiment revealed that fertilization in plantation improved organic carbon, soil available nitrogen, and available phosphorus [21]. Under same fertilization management, soil physicochemical properties were influenced widely by litter decomposition, rhizosphere secretions along enhancement of aboveground ground biomass (Table 1).

The SWC significantly decreased with increasing pomegranate stand age (Table 3). An investigation in apricot orchards had a similar result [41], where the soil water deficit increased with orchard stand age. Moreover, mature jujube trees primarily utilized subsurface water compared to young jujube trees [42]. Plantation canopy volume and yield increased with stand age, which required the storage of a large amount of soil water throughout the profile to meet increasing evapotranspiration demand [43]. Despite the same annual irrigation scheme, the soil water content of pomegranate plantation decreased with the increase of plantation stand age. Our results implied that the 10-year-old pomegranate trees required more water and more efficient irrigation style, especially under the dry conditions in the Yellow River floodplain.

\subsection{Soil Microbial Communities and Influential Factors}

Microbial activities have been shown as key indicators of soil quality. Therefore, how the soil microbial communities change with stand age is a critical scientific aspect in this man-made, long-term pure plantation. In our study, total microbial PLFAs, bacterial PLFAs, and fungal PLFAs significantly increased along pomegranate plantation stand ages $(p<0.01$, Table 2$)$. Some studies have documented that environmental factors have important influences on microbial community biomass and structure [10,44,45]. Among all factors, soil $\mathrm{C}$ availability may be a prime determinant of the diversification of soil microbial community $[5,46]$. The significant difference of soil microbial PLFAs in pomegranate plant stand age $(p<0.01)$ in our study mostly due to DOC. Furthermore, an experiment in subtropical China showed that $\mathrm{SOC}, \mathrm{NH}_{4}-\mathrm{N}$ and $\mathrm{NO}_{3}-\mathrm{N}$ were key factors affecting the soil microbial community regardless of plantation types [47]. In a site with rich organic carbon, microbial communities consistently exhibited the uniform distribution pattern regardless of soil water content and soil depths [10]. We also observed the increase of total PLFAs but $\mathrm{NH}_{4}-\mathrm{N}$ and $\mathrm{NO}_{3}-\mathrm{N}$ had no significant difference in different soil depths. Altogether, DOC was the most important influential factor to soil microbial community. We suggested that the higher microbial biomass in upper soil than deeper soil might also related to DOC content.

Phosphorus availability was expected to affect soil microbial community. However, redundancy analysis showed that $\mathrm{P}$ was not key factor to influence microbial biomass. In a long-term experiment in grassland, microbial phosphorus content was positively related to organic carbon but negatively related to organic phosphorus, suggesting that $\mathrm{C}$ and $\mathrm{N}$ were the limiting factors affecting microbial growth and activity, whereas $P$ was not [48]. In addition, soil microbes were insensitive to the elevated $\mathrm{P}$ availability in the spruce plantation and $\mathrm{P}$ addition might increase soil microbial biomass mainly through improving carbon availability [49]. In the other hand, phosphorus fertilization management reduced 
the biodiversity of AMF and showed a negative effect on AMF [50,51]. In our study, it was not certain about the impact of available phosphorus on soil microbial community.

Fungal bacterial dominance is a widely used metric that has provided the means to assess both the environmental impacts and the functional implications of soil microbial communities. Physical disturbance (tillage effect), soil nutrient, soil $\mathrm{pH}$, soil microclimate and other factors influenced the fungal: bacterial dominance $[35,52,53]$. As fungal and bacterial PLFAs significantly increased $177.13 \%$ and $128.68 \%$ with pomegranate plantation stand age (Figure $2 b, c$ ), the ratio of fungal PLFAs to bacterial PLFAs enhanced significantly (Figure 2d). Fungi typically exhibited a hyphal growth form, but most bacteria are present as individual cells. Less tillage and no-tillage management could result in less tissue damage for fungi [54]. Fungal community might have much more biomass along the plantation stand ages under no-tillage management. The extent of increased fungal PLFAs was more related the arbuscular mycorrhizal fungal PLFAs (166.61\%). These points indicted that the increase of fungal PLFAs was mainly due to the increase of arbuscular mycorrhizal fungal community. The ratio of fungi to bacteria was positively related to DOC and $\mathrm{NH}_{4}-\mathrm{N}$ $(p<0.01)$, and negatively related to SWC $(p<0.01)$ and $\mathrm{pH}(p<0.05)$ in the person analysis. Bossuyt et al. had reported the bacterial activity was more sensitive to low availability of $\mathrm{C}$ and $\mathrm{N}$ than fungi, while fungi preferred low quality substrates (high C: $\mathrm{N}$ ) [12]. We observed the ratio of available $\mathrm{C}$ to available $\mathrm{N}$ had been increased, and the fungal community might have had higher activity than the bacterial community. In general, it was proposed that fungi would exhibit fewer of responses to changes in moisture than bacteria because their chitinous cell walls make fungi more resistant and resilient to changes in moisture [55]. In addition, the relative higher fungal activities were found under warmer and drier environments and bacterial activities under colder and moister environments [56]. The lower SWC values in P5 and P10 were more beneficial to fungal community activities. Variation of soil $\mathrm{pH}$ in a wide range could influence fungal community and bacterial community biomass [57,58]. Soil $\mathrm{pH}$ decreased from 8.20 to 7.87 in our study which might conduct a weak influence on F/B ratio. Thus, we believed that the increased ratio of fungi to bacteria was due to more labile carbon and more AMF community biomass. Higher AMF community activities can not only improve the adaptation of pomegranate to drought environment, but also promote nutrient absorption and increase crop yield.

GP bacterial PLFAs and GN bacterial PLFAs increased along the pomegranate stand age at $0-10 \mathrm{~cm}$, but GP/GN ratio increased at $20-30 \mathrm{~cm}$ soil depth (Figure $3 \mathrm{a}-\mathrm{c}$ ). Kramer and Gleiner [59] proposed that GN bacteria used more organic plant-derived $C$ sources that were generally labile, while GP bacteria used more soil organic matter-derived C sources which were more recalcitrant. This point was verified by other similar studies $[60,61]$. The increase of DOC and AMF PLFAs might demonstrate more soil organic plant-derived C, which contributed to the decrease of the ratio of GP bacterial PLFAs to GN bacterial PLFAs at $0-10 \mathrm{~cm}$ soil depth. Besides, a previous study suggested that GP bacteria might be more drought tolerant than GN bacteria [62]. With the reduction of available water at 20-30-cm soil depth under similar contents of DOC, the activity of GN bacteria was more sensitive than GP bacteria. Less water sources might lead to the enhancement of the ratio of GP bacteria to GN bacteria. In general, the effects of plantation stand ages on the ratios of GP bacteria to GN bacteria varied among the three soil depths.

Our findings highlight that arbuscular mycorrhizal fungal PLFAs acted on the turnover of soil nutrients in agricultural plantation, which was consistent with a previous study that found the arbuscular mycorrhizal fungi were proved as major factor to the ecosystem functioning [63]. Higher soil nutrient and arbuscular mycorrhizal fungal biomass based on PLFAs profiles along the age sequence supported that pomegranate plantation was beneficial to soil properties and soil microbes. PLFA analysis could reveal some but not all information about microbial changes despite the rapid and extensive features. In the case of changes in soil microbial communities, more advanced approaches, such as nucleic acid base methods, can reveal specific population changes more accurately in the Yellow River floodplain. 


\section{Conclusions}

In this study, we represented a comprehensive understanding of the effects of pomegranate plantation stand age on the soil physicochemical properties and soil microbial community. The results revealed that long-term pomegranate plantation elevated soil nutrient availability and soil microbial PLFA contents. Long-term pomegranate plantation enhanced soil DOC, $\mathrm{NH}_{4}-\mathrm{N}$, AP, but caused soil water deficit. The ratios of fungi to bacteria and Gram-positive bacteria to Gram-negative bacteria were significantly influenced by soil nutrient availability. Our work not only provided evidence that microbial community PLFAs was affected by pomegranate plantation stand age, but also indicated that DOC was the key factor in labile substrates affecting microbial communities in pomegranate plantation in Yellow River floodplain. These results would further advance our understanding regarding about long-term plantation affected soil physicochemical properties and altered soil microbial communities in semi-arid region.

Supplementary Materials: The following are available online at https:/ /www.mdpi.com/article/10 .3390/d13090408/s1, Table S1: ANOVA of soil total PLFAs, bacterial PLFAs, fungal PLFAs, F/B ratios, GP bacterial PLFAs, GN bacterial PLFAs, the ratio of GP bacterial PLFAs to GN bacterial PLFAs and arbuscular mycorrhizal fungi (AMF) PLFAs in different soil depths $(0-10 \mathrm{~cm}, 10-20 \mathrm{~cm}$ and $20-30$ $\mathrm{cm}$ ) under pomegranate plantation of same year (a) and in same depth under different years (b). (P1, pomegranate plantation for 1 year; other names (P3; P5; P10) are in the same manner)

Author Contributions: Investigation, Y.M., S.W., L.Y., Q.X.; formal analysis, S.W., X.Y.; data curation and writing-original draft preparation, S.W.; writing—review and editing, S.W., D.W., I.A.S., J.C., C.Z., Y.M.; funding acquisition, Y.M., S.H. All authors have read and agreed to the published version of the manuscript.

Funding: This research was financially supported by the National Natural Science Foundation of China (41930643), Henan Province Foundation and Advanced Technology Project (192102110085), Chen received funding from H2020 Marie Skłodowska-Curie Actions (No. 839806), Aarhus Universitets Forskningsfond (AUFF-E-2019-7-1), and Nordic Committee of Agriculture and Food Research.

Institutional Review Board Statement: Not applicable.

Data Availability Statement: Not applicable.

Acknowledgments: We thank Jingting Qin for contribution in the site map in Figure 1. All authors provided intellectual input and assistance for this study and for preparing the manuscript.

Conflicts of Interest: The authors declare no conflict of interest.

\section{References}

1. Okhovatian-Ardakani, A.R.; Mehrabanian, M.; Dehghani, F.; Akbarzadeh, A. Salt tolerance evaluation and relative comparison in cuttings of different pomegranate cultivar. Plant Soil Environ. 2010, 56, 176-185. [CrossRef]

2. Aseri, G.K.; Jain, N.; Panwar, J.; Rao, A.V.; Meghwal, P.R. Biofertilizers improve plant growth, fruit yield, nutrition, metabolism and rhizosphere enzyme activities of pomegranate (Punica granatum, L.) in Indian Thar Desert. Sci. Hortic. 2008, 117, 130-135. [CrossRef]

3. Volschenk, T. Water use and irrigation management of pomegranate trees-A review. Agric. Water Manag. 2020, $241,106375$. [CrossRef]

4. Zhang, Q.; Wu, J.; Yang, F.; Lei, Y.; Zhang, Q.; Cheng, X. Alterations in soil microbial community composition and biomass following agricultural land use change. Sci. Rep. 2016, 6, 36587. [CrossRef] [PubMed]

5. Yao, H.; Bowman, D.; Shi, W. Soil microbial community structure and diversity in a turfgrass chronosequence: Land-use Change versus turfgrass management. Appl. Soil Ecol. 2006, 34, 209-218. [CrossRef]

6. Zipfel, C.; Oldroyd, G.E.D. Plant signalling in symbiosis and immunity. Nature 2017, 543, 328-336. [CrossRef]

7. Seiwa, K.; Negishi, Y.; Eto, Y.; Hishita, M.; Masaka, K.; Fukasawa, Y.; Matsukura, K.; Suzuki, M. Successful seedling establishment of arbuscular mycorrhizal-compared to ectomycorrhizal-associated hardwoods in arbuscular cedar plantations. For. Ecol. Manag. 2020, 468, 118155. [CrossRef]

8. Gao, D.; Zhou, X.; Duan, Y.; Fu, X.; Wu, F. Wheat cover crop promoted cucumber seedling growth through regulating soil nutrient resources or soil microbial communities? Plant Soil 2017, 418, 1-17. [CrossRef]

9. Yeoh, Y.K.; Dennis, P.G.; Paungfoo-Lonhienne, C.; Weber, L.; Brackin, R.; Ragan, M.A.; Schmidt, S.; Hugenholtz, P. Evolutionary Conservation of a Core Root Microbiome across Plant Phyla along a Tropical Soil Chronosequence. Nat. Commun. 2017,8 , 215. [CrossRef] 
10. Zhou, J.; Xia, B.; Treves, D.S.; Wu, L.-Y.; Marsh, T.L.; O’Neill, R.V.; Palumbo, A.V.; Tiedje, J.M. Spatial and resource factors influencing high microbial diversity in soil. Appl. Environ. Microbiol. 2002, 68, 326-334. [CrossRef]

11. Zhou, X.; Liu, J.; Wu, F. Soil microbial communities in cucumber monoculture and rotation systems and their feedback effects on cucumber seedling growth. Plant Soil 2017, 415, 507-520. [CrossRef]

12. Chen, J.; Luo, Y.; van Groenigen, K.J.; Hungate, B.A.; Cao, J.; Zhou, X.; Wang, R.W. A keystone microbial enzyme for nitrogen control of soil carbon storage. Sci. Adv. 2018, 4, eaaq1689. [CrossRef] [PubMed]

13. Munro, P.; Forge, T.A.; Jones, M.D.; Nelson, L.M. Soil biota from newly established orchards are more beneficial to early growth of cherry trees than biota from older orchards. Appl. Soil Ecol. 2020, 155, 103658. [CrossRef]

14. Chen, J.; Luo, Y.; Li, J.; Zhou, X.; Cao, J.; Wang, R.W.; Wang, Y.; Shelton, S.; Jin, Z.; Walker, L.M.; et al. Costimulation of soil glycosidase activity and soil respiration by nitrogen addition. Glob. Chang. Biol. 2017, 23, 1328-1337. [CrossRef]

15. Sharma, S.D.; Kumar, P.; Bhardwaj, S.K.; Chandel, A. Agronomic performance, nutrient cycling and microbial biomass in soil as affected by pomegranate based multiple crop sequencing. Sci. Hortic. 2015, 197, 504-515. [CrossRef]

16. Fierer, N.; Jackson, R.B. The diversity and biogeography of soil bacterial communities. Proc. Natl. Acad. Sci. USA 2006, 103, 626-631. [CrossRef]

17. Spring, A.M.; Domingue, K.D.; Kerber, T.V.; Mooney, M.M.; Hale, R.L.; Lemmer, K.M.; Docherty, K.M. Land use effects on airborne bacterial communities are evident in both near-surface and higher-altitude air. Diversity 2021, 13, 85. [CrossRef]

18. Wang, D.; Huang, X.; Qiao, N.; Geng, Q.; Liu, Y.; Song, H.; Yang, Z.; Liu, C.; Wang, G. Effects of mowing and fertilization on soil quality in a semiarid grassland of North China. Land Degrad. Dev. 2021, 32, 1656-1666. [CrossRef]

19. Liu, J.; Sui, Y.; Yu, Z.; Shi, Y.; Chu, H.; Jin, J.; Liu, X.; Wang, G. High throughput sequencing analysis of biogeographical distribution of bacterial communities in the black soils of northeast China. Soil Biol. Biochem. 2014, 70, 113-122. [CrossRef]

20. Rousk, J.; Brookes, P.; Bååth, E. Investigating the mechanisms for the opposing PH relationships of fungal and bacterial growth in soil. Soil Biol. Biochem. 2010, 42, 926-934. [CrossRef]

21. Zhong, Z.; Huang, X.; Feng, D.; Xing, S.; Weng, B. Long-term effects of legume mulching on soil chemical properties and bacterial community composition and structure. Agric. Ecosyst. Environ. 2018, 268, 24-33. [CrossRef]

22. Yu, Q.; Hanif, A.; Rao, X.; He, J.; Sun, D.; Liu, S.; He, D.; Shen, W. Long-term restoration altered edaphic properties and soil microbial communities in forests: Evidence from four plantations of southern China. Restor. Ecol. 2021, 4, e13354.

23. Zheng, J.; Chen, J.; Pan, G.; Wang, G.; Liu, X.; Zhang, X.; Li, L.; Bian, R.; Cheng, K.; Zheng, J. A long-term hybrid poplar plantation on cropland reduces soil organic carbon mineralization and shifts microbial community abundance and composition. Appl. Soil Ecol. 2017, 111, 94-104. [CrossRef]

24. Frostegård, Å.; Tunlid, A.; Bååth, E. Use and misuse of PLFA measurements in soils. Soil Biol. Biochem. 2011, 43, 1621-1625. [CrossRef]

25. Frostegård, A.; Bååth, E. The use of phospholipid fatty acid analysis to estimate bacterial and fungal biomass in soil. Biol. Fertil. Soils 1996, 22, 59-65. [CrossRef]

26. Ramsey, P.W.; Rillig, M.C.; Feris, K.P.; Holben, W.E.; Gannon, J.E. Choice of methods for soil microbial community analysis: PLFA maximizes power compared to CLPP and PCR-based approaches. Pedobiologia 2006, 50, 275-280. [CrossRef]

27. Galindo, A.; Rodríguez, P.; Collado-González, J.; Cruz, Z.N.; Torrecillas, E.; Ondoño, S.; Corell, M.; Moriana, A.; Torrecillas, A. Rainfall intensifies fruit peel cracking in water stressed pomegranate trees. Agric. For. Meteorol. 2014, 194, 29-35. [CrossRef]

28. An, S.; Mentler, A.; Mayer, H.; Blum, W.E.H. Soil aggregation, aggregate stability, organic carbon and nitrogen in different soil aggregate fractions under forest and shrub vegetation on the loess plateau, China. CATENA 2010, 81, 226-233. [CrossRef]

29. Deurer, M.; Grinev, D.; Young, I.; Clothier, B.E.; Müller, K. The impact of soil carbon management on soil macropore structure: A comparison of two apple orchard systems in New Zealand. Eur. J. Soil Sci. 2009, 60, 945-955. [CrossRef]

30. Fiske, C.H.; Subbarow, Y. The colorimetric determination of phosphorus. J. Biol. Chem. 1925, 66, 375-400. [CrossRef]

31. Bossio, D.A.; Scow, K.M. Impacts of carbon and flooding on soil microbial communities: Phospholipid fatty acid profiles and substrate utilization patterns. Microb. Ecol. 1998, 35, 265-278. [CrossRef]

32. Zelles, L.; Bai, Q.Y.; Beck, T.; Beese, F. Signature fatty acids in phospholipids and lipopolysaccharides as indicators of microbial biomass and community structure in agricultural soils. Soil Biol. Biochem. UK 1992, 24, 317-323. [CrossRef]

33. Abaye, D.A.; Lawlor, K.; Hirsch, P.R.; Brookes, P.C. Changes in the microbial community of an arable soil caused by long-term metal contamination. Eur. J. Soil Sci. 2005, 56, 93-102. [CrossRef]

34. Tunlid, A.; Hoitink, H.A.; Low, C.; White, D.C. Characterization of bacteria that suppress rhizoctonia damping-off in bark compost media by analysis of fatty acid biomarkers. Appl. Environ. Microbiol. 1989, 55, 1368-1374. [CrossRef] [PubMed]

35. Zhou, W.P.; Shen, W.J.; Li, Y.E.; Hui, D.F. Interactive effects of temperature and moisture on composition of the soil microbial community. Eur. J. Soil Sci. 2017, 68, 909-918. [CrossRef]

36. Zelles, L.; Rackwitz, R.; Bai, Q.; Beck, T.; Beese, F. Discrimination of microbial diversity by fatty acid profiles of phospholipids and lipo-polysaccharids in differently cultivated soils. Plant Soil 1995, 170, 115-122. [CrossRef]

37. Kaiser, C.; Frank, A.; Wild, B.; Koranda, M.; Richter, A. Negligible contribution from roots to soil-borne phospholipid fatty acid fungal biomarkers 18:2w6,9 and 18:1w9. Soil Biol. Biochem. 2010, 42, 1650-1652. [CrossRef]

38. Wang, Q.Y.; Zhou, D.-M.; Cang, L. Microbial and Enzyme properties of apple orchard soil as affected by long-term application of copper fungicide. Soil Biol. Biochem. 2009, 41, 1504-1509. [CrossRef] 
39. He, S.; Zheng, Z.; Zhu, R. Long-term tea plantation effects on composition and stabilization of soil organic matter in southwest China. CATENA 2021, 199, 105132. [CrossRef]

40. Wang, D.; Chi, Z.; Yue, B.; Huang, X.; Zhao, J.; Song, H.; Yang, Z.; Miao, R.; Liu, Y.; Zhang, Y.; et al. Effects of mowing and nitrogen addition on the ecosystem $\mathrm{c}$ and $\mathrm{n}$ pools in a temperate steppe: A case study from northern China. CATENA 2020, 185, 104332. [CrossRef]

41. Yang, K.; Wang, K.; Zhang, X.; Chang, X.; Bai, G.; Zheng, J.; Wu, G.-L. Change in soil water deficit and soil organic matter consumption over time in rain-fed apricot orchards on the semi-arid loess plateau, China. Agric. Ecosyst. Environ. 2021, 314, 107381. [CrossRef]

42. Huo, G.; Zhao, X.; Gao, X.; Wang, S.; Pan, Y. Seasonal water use patterns of rainfed jujube trees in stands of different ages under semiarid plantations in China. Agric. Ecosyst. Environ. 2018, 265, 392-401. [CrossRef]

43. Gao, X.; Li, H.; Zhao, X.; Ma, W.; Wu, P. Identifying a suitable revegetation technique for soil restoration on water-limited and degraded land: Considering both deep soil moisture deficit and soil organic carbon sequestration. Geoderma 2018, 319, 61-69. [CrossRef]

44. Lauber, C.L.; Strickland, M.S.; Bradford, M.A.; Fierer, N. The influence of soil properties on the structure of bacterial and fungal communities across land-use types. Soil Biol. Biochem. 2008, 40, 2407-2415. [CrossRef]

45. Wang, D.; Chen, J.; Felton, A.J.; Xia, L.; Zhang, Y.; Luo, Y.; Cheng, X.; Cao, J. Post-fire co-stimulation of gross primary production and ecosystem respiration in a meadow grassland on the tibetan plateau. Agric. For. Meteorol. 2021, 303, 108388. [CrossRef]

46. Degens, B. Decreases in organic $\mathrm{C}$ reserves in soils can reduce the catabolic diversity of soil microbial communities. Soil Biol. Biochem. 2000, 32, 189-196. [CrossRef]

47. Huang, X.; Liu, S.; Wang, H.; Hu, Z.; Li, Z.; You, Y. Changes of soil microbial biomass carbon and community composition through mixing nitrogen-fixing species with eucalyptus urophylla in subtropical China. Soil Biol. Biochem. 2014, 73, 42-48. [CrossRef]

48. Katsalirou, E.; Deng, S.; Gerakis, A.; Nofziger, D.L. Long-term management effects on soil P, microbial biomass P, and phosphatase activities in prairie soils. Eur. J. Soil Biol. 2016, 76, 61-69. [CrossRef]

49. Huang, J.; Hu, B.; Qi, K.; Chen, W.; Pang, X.; Bao, W.; Tian, G. Effects of phosphorus addition on soil microbial biomass and community composition in a subalpine spruce plantation. Eur. J. Soil Biol. 2016, 72, 35-41. [CrossRef]

50. Jiang, F.; Zhang, L.; Zhou, J.; George, T.S.; Feng, G. Arbuscular mycorrhizal fungi enhance mineralisation of organic phosphorus by carrying bacteria along their extraradical hyphae. New Phytol. 2021, 230, 304-315. [CrossRef]

51. Sheng, M.; Lalande, R.; Hamel, C.; Ziadi, N. Effect of long-term tillage and mineral phosphorus fertilization on arbuscular mycorrhizal fungi in a humid continental zone of eastern Canada. Plant Soil 2013, 369, 599-613. [CrossRef]

52. Bailey, V.L.; Smith, J.L.; Bolton, H. Fungal-to-bacterial ratios in soils investigated for enhanced C sequestration. Soil Biol. Biochem. 2002, 34, 997-1007. [CrossRef]

53. Bååth, E.; Frostegard, A.; Pennanen, T.; Fritze, H. Microbial community structure and PH response in relation to soil organic matter quality in wood-ash fertilized, clear-cut or burned coniferous forest soils. Soil Biol. Biochem. 1995, 27, 229-240. [CrossRef]

54. Helgason, B.L.; Walley, F.L.; Germida, J.J. Fungal and bacterial abundance in long-term no-till and intensive-till soils of the northern great plains. Soil Sci. Soc. Am. J. 2009, 73, 120-127. [CrossRef]

55. Holland, E.A.; Coleman, D.C. Litter placement effects on microbial and organic matter dynamics in an agroecosystem. Ecology 1987, 68, 425-433. [CrossRef]

56. Stromberger, M.; Shah, Z.; Westfall, D. Soil microbial communities of no-till dryland agroecosystems across an evapotranspiration gradient. Appl. Soil Ecol. 2007, 35, 94-106. [CrossRef]

57. Fernández-Calviño, D.; Rousk, J.; Brookes, P.C.; Bååth, E. Bacterial PH-optima for growth track soil PH, but are higher than expected at low PH. Soil Biol. Biochem. 2011, 43, 1569-1575. [CrossRef]

58. Bååth, E.; Anderson, T.-H. Comparison of Soil Fungal/Bacterial Ratios in a PH Gradient Using Physiological and PLFA-Based Techniques. Soil Biol. Biochem. 2003, 35, 955-963. [CrossRef]

59. Kramer, C.; Gleixner, G. Soil organic matter in soil depth profiles: Distinct carbon preferences of microbial groups during carbon transformation. Soil Biol. Biochem. 2008, 40, 425-433. [CrossRef]

60. Sekhohola-Dlamini, L.; Dlamini, P.; Selvarajan, R.; Ogola, H.J.O.; Tekere, M. Influences of geochemical factors and substrate availability on gram-positive and gram-negative bacterial distribution and bio-processes in ageing municipal landfills. Int. Microbiol. 2021, 24, 311-332. [CrossRef]

61. Fanin, N.; Kardol, P.; Farrell, M.; Nilsson, M.C.; Gundale, M.J.; Wardle, D.A. The ratio of gram-positive to gram-negative bacterial PLFA markers as an indicator of carbon availability in organic soils. Soil Biol. Biochem. 2019, 128, 111-114. [CrossRef]

62. Orwin, K.H.; Dickie, I.A.; Wood, J.R.; Bonner, K.I.; Holdaway, R.J. Soil microbial community structure explains the resistance of respiration to a dry-rewet cycle, but not soil functioning under static conditions. Funct. Ecol. 2016, 30, 1430-1439. [CrossRef]

63. Van der Heijden, M.G.A.; Klironomos, J.N.; Ursic, M.; Moutoglis, P.; Streitwolf-Engel, R.; Boller, T.; Wiemken, A.; Sanders, I.R. Mycorrhizal fungal diversity determines plant biodiversity, ecosystem variability and productivity. Nature 1998, 396, 69-72. [CrossRef] 